\title{
Production of sorbitol by repeated batch fermentation using immobilized of Lactobacillus plantarum strain (BAA-793) via solid state fermentation
}

\author{
Zuriana, S.A. and *Sakinah, A.M.M. \\ Faculty of Technology Engineering, Universiti Malaysia Pahang (UMP), 26600, Kuantan, Pahang, \\ Malaysia
}

\begin{abstract}
Article history:
Received: 10 June 2017 Received in revised form: 18 June 2017

Accepted: 17 July 2017

Available Online: 18 July 2017
\end{abstract}

Keywords:

Repeated batch

fermentation,

Solid state fermentation,

Immobilization,

Sodium alginate

DOI:

http://doi.org/10.26656/ fr.2017.5.064

\begin{abstract}
Sorbitol production from Meranti wood sawdust (MWS) using immobilized cells of Lactobacillus plantarum (BAA-793) with repeated batch fermentation via solid state fermentation (SSF) was studied. The storage stability of the immobilized cells, entrapped in sodium alginate beads was also investigated. This study started with the pretreatment of the MWS to recover the cellulose, followed by the entrapment of the bacterial cells in sodium alginate, then the fermentation process via SSF. The results showed that the storage stability of the immobilized cells in gel beads at $4^{\circ} \mathrm{C}$ were more stable when compared to stability at $35^{\circ} \mathrm{C}$, even with high cell concentration. The cell concentration, when stored at $4^{\circ} \mathrm{C}$ showed great stability up to 2 days but started to decrease slightly as the storage time was extended to 5 days. The concentration of the cells was about log $10.23 \mathrm{CFU} / \mathrm{mL}\left(1.70 \times 10^{10} \mathrm{CFU} / \mathrm{mL}\right)$ after 2 days, and $\log 9.48 \mathrm{CFU} / \mathrm{mL}\left(3.00 \times 10^{9}\right.$ $\mathrm{CFU} / \mathrm{mL}), \log 9.47 \mathrm{CFU} / \mathrm{mL}\left(2.98 \times 10^{9} \mathrm{CFU} / \mathrm{mL}\right)$ and $\log 9.44 \mathrm{CFU} / \mathrm{mL}\left(2.80 \times 10^{9}\right.$ $\mathrm{CFU} / \mathrm{mL}$ ) after 3 to 5 days, respectively. The decrease in the concentration was not significant within the studied period of storage at $4^{\circ} \mathrm{C}$. The repeated batch fermentation for sorbitol production through the reuse of the entrapped cells showed that the same bead cells can be reused for the fermentation process up to 5 cycles. The production of sorbitol using the immobilized cells of Lactobacillus plantarum (BAA-793) through solid state fermentation process showed a good result due to the high concentration of cells entrapped in the beads, giving rise to a high sorbitol production.
\end{abstract}

\section{Introduction}

Generally, sorbitol belongs to the sugar alcohol group of polyols. Sorbitol is also the most important polyol bulk sweetener and has been in use as a sweetener for diabetics since the early 1930's (Nezzal et al., 2009). Sorbitol and other polyols have been used to reduce intracranial pressure (ICP) since the early 1960s (Barros et al., 2006; Saha, 2006). The real breakthrough came when the first sugar-free confectionery products were launched in the late 1970's. Those products focused on health aspects such as reducing the calorie content in many types of foods, reducing tooth decay, and as a sugar substitute, but were not specifically designed nor were they suitable for diabetics. Furthermore, novel dairy products enriched in polyols were developed in order to reduce diabetes (Ladero et al., 2007; Kumar and Murugalatha, 2012).
Solid state fermentation (SSF) can be described as the cultivation of microorganisms in the absence of free water under controlled conditions (Pandey et al., 2001). Generally, SSF has been utilized to convert moist agricultural polymeric substrates such as soy, rice, sawdust, wheat and other substrates into fermented food products including industrial enzymes, fuel, and nutrient enriched animal feeds (Pandey, Palni and Bisht 2001; Pandey et al., 2004). In addition, solid state fermentation was preferred to liquid state fermentation because of being a simple technique, having low wastewater output (liquid waste is not produced), less chances of contamination, low capital investment (cheaper costs), lower levels of catabolite repression, better product recovery, less time-consuming and higher quality of production (Manpreet et al., 2005).

Generally, the physical confinement or localization of the intact cells to a certain region of space without 
loss of desired biological activity is called immobilization of whole cells (Pilkingtonn et al., 1998; Ibrahim et al., 2013; Amenaghawon and Oiwoh, 2015). The immobilization of whole cells plays an important role in microbial ecology and is widespread in nature. Whole cell immobilization occurs to some extent in all microbe-based industrial processes as well, including water and wastewater treatment (Pilkingtonn et al., 1998; Ibrahim et al., 2013; Amenaghawon and Oiwoh, 2015). Before this, the immobilization of whole cells process and its application in the bioprocessing has been interesting for 30 years and it also has introduced in industrials (Behera et al., 2011). Besides that, immobilization also consists immobilizing cells of microorganism inside or on the surface of a carrier in a way that preserves their catalytic activity (Jack and Zajic, 2006). Based on previous research, immobilization cells systems are classified according to the mechanism of immobilization. Cells Immobilization has many types of methods such as physical entrapment within the porous matrix, adsorption, encapsulation, covalent binding to a carrier and cross-linking of cells. Currently, $50 \%$ of the world's supply of biochemicals such as lactic acid, sorbitol, bioethanol and other biochemical products are provided through free cell fermentation, but the productivity of the fermentation process is very low. However, employing the cell immobilization technique that provides high density can increase the productivity of generating biochemical products. Besides that, the immobilization process is one of the most attractive methods for maintaining high cell concentration in a bioreactor for processing biochemical products (Gündüz, 2005; Cláudia et al., 2013). The cell immobilization system offers the greatest advantages for several industrial process, such as having an easy to handle biocatalyst, easy separation of biological materials from the reaction medium, employing high cell loading capacity, improving the production rate of products and other advantages (Bayat et al., 2015; Tallur et al., 2015).

The present work has a focus on storage stability of cells immobilization and repeated batch fermentation using immobilized cells employing entrapment technique due to sorbitol production.

\section{Materials and methods}

\subsection{Materials and culture}

The raw material used was Meranti wood sawdust, which was obtained from Kilang Kayu Aman Sdn Bhd, Gambang Kuantan, Pahang. Meranti wood sawdust is of the hardwood type that contains a high cellulose content compared to other types. Meranti wood sawdust was taken by bulk from the sawmill plant in order to make sure the quality of the materials was the same throughout the research. The bacterial strain that was used in this study was Lactobacillus plantarum (BAA-793). The bacterial strain was purchased from the America Type Culture Collection (ATCC) type.

\subsection{Preparation of cellulose extraction}

Meranti wood sawdust (MWS) must first be treated using physical pre-treatment (cutting, milling, and drying) and chemical pre-treatment. Chemical pretreatment involved a pre de-lignification process using sodium hydroxide $(\mathrm{NaOH})$, with the first stage of the pre -treatment process using peracetic acid $\left(\mathrm{CH}_{3} \mathrm{COOH}\right)$ and the second stage using sulfuric acid $\left(\mathrm{H}_{2} \mathrm{SO}_{4}\right)$ (Zhang et al., 2006; Zhao et al., 2008; Fang et al., 2010; Rusmawarni, 2011).

The type of bacteria used in this study was Lactobacillus plantarum (BAA- 793), which was purchased from America Type Culture Collection (ATCC). This strain is an anaerobic bacteria type. To handle this bacterium, the anaerobic condition must be applied in order to get a good growth of the bacterium.

\subsection{Culture preparation}

The bacterium was cultivated under anaerobic condition in the MRS medium for 24 hours at $30^{\circ} \mathrm{C}$ inside incubators (Ladero et al., 2007). The liquid medium of MRS was used for inoculum preparation. $100 \mathrm{ml}$ of MRS medium was transferred into $250 \mathrm{ml}$ Schott bottles and one loop of bacteria (Lactobacillus plantarum) from the agar plate was transferred into 100 $\mathrm{ml}$ of MRS medium. Then, nitrogen gas $\left(\mathrm{N}_{2}\right)$ was used to purge the Schott bottles that contained the MRS medium and bacteria in order to remove the oxygen gas $\left(\mathrm{O}_{2}\right)$ inside the Schott bottles and to maintain the anaerobic condition during the cultivation process. Then, it was kept in an incubator at $30^{\circ} \mathrm{C}$. After 24 hours of cultivation, the optical density of the inoculums was checked using UV-Vis Spectrophotometer. The optical density was taken at a wavelength equal to $600 \mathrm{~nm}$ $\left(\mathrm{OD}_{600}\right)$. The values of $\mathrm{OD}_{600}$ should be less than 0.4 or 0.1 to 0.2 for successful cultivation (Sabu et al., 2008).

\subsection{Cells immobilization}

The bacteria (Lactobacillus plantarum) cells that were grown in MRS broth were mixed with an equal medium volume of $2 \%$ Na-alginate solution $(1: 1, \mathrm{v} / \mathrm{v})$. Then, after being mixed, the alginate-cell solution was dropped slowly into $0.2 \%$ of calcium chloride $\left(\mathrm{CaCl}_{2}\right)$ 
solution using a syringe needle. After that, the alginate solidified when it made contact with the $\mathrm{CaCl}_{2}$ solution and formed gels beads, thus entrapping the bacteria cells. The beads were allowed to harden in $\mathrm{CaCl}_{2}$ solution for 30 minutes. Then the beads were washed with $0.85 \%$ of $\mathrm{NaCl}$ solution and distilled water to remove excess calcium ion and cells. The beads were stored at $4{ }^{\circ} \mathrm{C}$ for further experiments. To improve the immobilization results, the ratio of $\mathrm{CaCl}_{2}(0.2 \%)$ and $\mathrm{NaCl}(0.85 \%)$ that were used in solution preparation was $1: 1, \mathrm{v} / \mathrm{v}$ (Yan et al., 2001; Bangrak et al., 2011; El-Borai et al., 2013).

\subsection{Storage stability}

The storage stability of immobilized cells in beads (entrapped in Na-alginate) was also investigated in order to measure cell concentration and population. The gel beads were stored at $4^{\circ} \mathrm{C}$ in the freezer and $35^{\circ} \mathrm{C}$ in an incubator. The storage time varied from 1 to 7 days for both conditions. Then, the cell numbers were counted using plate counting.

\subsection{Immobilization cells storage}

The gel beads that were stored at $4^{\circ} \mathrm{C}$ for 2 to 5 days were used for repeated batch fermentation and no significant reduction of cell concentration occurred during this time period.

\subsection{Colony counting}

Ten dried gel beads containing bacteria cells were depolymerized in $10 \mathrm{~mL}$ of $1 \%(\mathrm{w} / \mathrm{v})$ sodium citrate solution using a $100 \mathrm{ml}$ beaker with gentle shaking for 20 minutes at room temperature in order to produce a cell suspension. After that, the cells suspension was serially diluted using pour plate method and incubated at $35^{\circ} \mathrm{C}$ for 3 days. The plates with 30 to 300 colonies were valid for use, while the plates with more than 300 colonies could not be counted and were referred to as too many to count (TMTC). Meanwhile, plates with fewer than 30 colonies were also not valid for colony counting and were referred to as too few to count (TFTC). The equation for colony counting is shown below

$$
\mathrm{CFU} / \mathrm{mL}=\frac{\text { Number of Colonies (CFUs) }}{\text { Dilution } \times \text { Amount Plates }}
$$

\subsection{Fermentation of cellulose using SSF process}

Two grams of the sample were put into a $100 \mathrm{ml}$ Erlenmeyer conical flask, then it was moistened with $50 \%$ of distilled water in order to achieve the desired moisture content (Sabu et al., 2008; Natarajan and Rajendran, 2012). All the apparatus and materials were sterilized at $121^{\circ} \mathrm{C}$ for 15 minutes to avoid contamination
(Natarajan and Rajendran, 2012). This experiment was conducted in a laminar flow to avoid contamination and loss of viability. After the sterilizing process, the samples were cooled. Then, $10 \%$ of beads of immobilized cells were put into the samples (Yan et al., 2001; Hsieh and Yang, 2004; Bangrak et al., 2011; El-Borai et al., 2013). The samples were purged with nitrogen gas in order to remove oxygen gas to maintain the anaerobic condition and then they were incubated at $35^{\circ} \mathrm{C}$. All the experiments were carried out in 3 sets to get their average values.

\subsection{Repeated batch fermentation}

The recycling of immobilized bacteria cells (gel beads) was studied in order to calculate how many cycles the gel beads could be used for sorbitol production. For this step, the condition parameters for fermentation followed the optimization values, which were fermentation time: 4 hours, substrate amount: $1.0 \mathrm{~g}$ and moisture content: $50 \%$. After finishing one cycle of fermentation, the beads inside the samples were collected and washed using sterilized distilled water for reuse in the next cycle of fermentation.

\subsection{Analysis methods}

The sorbitol production was determined using HighPerformance Liquid Chromatography, (HPLC Agilent, 1200 series). The column for the quantification of sorbitol was Rezex Chromatographic Method, RCM Monosaccharides $300 \times 7.8 \mathrm{~mm}$ with water as a mobile phase. The sugar was eluted with deionized water at a flow rate $0.6 \mathrm{~mL} / \mathrm{min}$ and the column, maintained at $75^{\circ} \mathrm{C}$ with the retention time is $30 \mathrm{~min}$. This method used Refractive Index, RI as a detector (Saha and Nakamura, 2003).

\subsection{Electron microscopic scanning}

The external appearance and surface structure of the beads were observed using scanning electron micrograph (SEM). The beads of bacteria were dried in an oven for 1 day in order to remove the moisture content. The beads were observed and examined using scanning electron micrograph (SEM).

\section{Result and discussion}

\subsection{Effect of storage stability on cell viability}

Determining the storage stability of immobilized cells for either short-term storage or long-term storage is an important procedure in the immobilization process and is also an essential factor for practical application of 
immobilized cell system (Ying et al., 2007). In this study, storage stability was investigated in order to determine the cell viability of Lactobacillus plantarum. Figure 1 shows a graph representing the storage stability of immobilized Lactobacillus plantarum (BAA-793) bacteria cells that were stored at $4^{\circ} \mathrm{C}$ and $35^{\circ} \mathrm{C}$.

Storage stability of Immobilized cell at $4^{\circ} \mathrm{C}$ and $3^{\circ} \mathrm{C}$

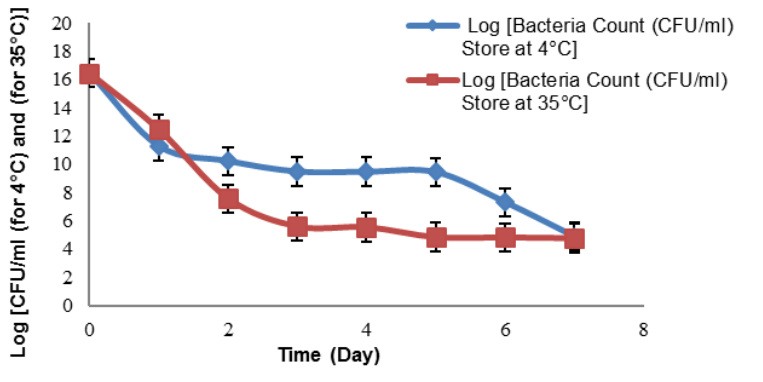

Figure 1. The storage stability of immobilized cells at $4^{\circ} \mathrm{C}$ and $35^{\circ} \mathrm{C}$

Based on Figure 1, the initial concentration of viable cells before storage at $4{ }^{\circ} \mathrm{C}$ and $35^{\circ} \mathrm{C}$ that was represented at $\left(\mathrm{t}_{0}\right)$ was about $\log 16.46 \mathrm{CFU} / \mathrm{ml}\left(2.90 \times 10^{16} \mathrm{CFU} /\right.$ $\mathrm{ml})$, in which the concentration of cells was very high because the cells were still fresh/concentrated after being immobilized using Na-alginate. Then, after storage at $4^{\circ}$ $\mathrm{C}$ for 1 day, the concentration of cells decreased to $\log$ $11.29 \mathrm{CFU} / \mathrm{ml}\left(1.95 \times 10^{11} \mathrm{CFU} / \mathrm{ml}\right)$. Otherwise, after storage at $35^{\circ} \mathrm{C}$ for 1 to 3 days, the cell concentration decreased to $\log 12.47 \mathrm{CFU} / \mathrm{ml}\left(2.98 \times 10^{12} \mathrm{CFU} / \mathrm{ml}\right)$, $\log 7.58 \mathrm{CFU} / \mathrm{ml}\left(3.70 \times 10^{7} \mathrm{CFU} / \mathrm{ml}\right)$ and $\log 5.60$ $\mathrm{CFU} / \mathrm{ml}\left(4.00 \times 10^{5} \mathrm{CFU} / \mathrm{ml}\right)$ on day 1 , day 2 and day 3 , respectively. The concentration of cells that were stored at $35^{\circ} \mathrm{C}$ was lower compared to storage at $4{ }^{\circ} \mathrm{C}$ because the compatibility of temperature is important in order to maintain the cell concentration. Meanwhile, the cell concentration at $4^{\circ} \mathrm{C}$ was maintained and started to stabilize at 2 to 5 days, where the cell concentrations were about $\log 10.23 \mathrm{CFU} / \mathrm{ml}\left(1.70 \times 10^{10} \mathrm{CFU} / \mathrm{ml}\right), \log$ $9.48 \mathrm{CFU} / \mathrm{ml}\left(3.00 \times 10^{9} \mathrm{CFU} / \mathrm{ml}\right), \log 9.47 \mathrm{CFU} / \mathrm{ml}$ $\left(2.98 \times 10^{9} \mathrm{CFU} / \mathrm{ml}\right)$ and $\log 9.44 \mathrm{CFU} / \mathrm{ml}\left(2.80 \times 10^{9}\right.$ $\mathrm{CFU} / \mathrm{ml}$ ) on day 2 , day 3 , day 4 and day 5 , respectively, and no significant reduction of cell concentration occurred during this time period. Lakshmi and Hemalatha (2015) reported that the time required for stabilization of cell content in the gel bead is approximately 48 hours of cultivation. Then, after 5 days of storage at $4^{\circ} \mathrm{C}$, the cell concentration decreased until day 7. Otherwise, at $35^{\circ} \mathrm{C}$ storage, cell concentration was maintained from day 3 until day 7, whereby the cells concentrations were about $\log 5.60 \mathrm{CFU} / \mathrm{ml}\left(4.00 \times 10^{5}\right)$, $\log 5.55 \mathrm{CFU} / \mathrm{ml}\left(3.60 \times 10^{5} \mathrm{CFU} / \mathrm{ml}\right), \log 4.84 \mathrm{CFU} / \mathrm{ml}$ $\left(7.00 \times 10^{4} \mathrm{CFU} / \mathrm{ml}\right), \log 4.82 \mathrm{CFU} / \mathrm{ml}\left(6.70 \times 10^{4} \mathrm{CFU} /\right.$ $\mathrm{ml})$ and $\log 4.77 \mathrm{CFU} / \mathrm{ml}\left(6.00 \times 10^{4} \mathrm{CFU} / \mathrm{ml}\right)$ on day 4 , day 5 , day 6 , day 7 and day 8 , respectively. Besides that, these values had no significant reduction of cell concentration. In addition, the above observations from Figure 1 suggest that the immobilized cells of Lactobacillus plantarum (BAA-793) were more stable at $4^{\circ} \mathrm{C}$ when compared to $35^{\circ} \mathrm{C}$. This is also consistent with other researchers (Geethanjali and Subash., 2013) who reported that immobilized enzymes are more stable at $4^{\circ}$ $\mathrm{C}$ when compared to $25^{\circ} \mathrm{C}$, since $4^{\circ} \mathrm{C}$ is the suitable temperature for the storage of most enzymes. In addition, storage stability is also related to accelerated stability, which is the stability of products with a predicted shelf life that is used to compare the relative stability of alternative formulations (Bajaj et al., 2012). The concept of accelerated stability is based on the Arrhenius equation (2), which is shown below, and also a modified Arrhenius equation (3) (Anderson et al., 1991; Bajaj et al., 2012).

$$
\ln K=\ln A \frac{\Delta E}{R T}
$$

From the equation (2), $\mathrm{K}$ is degradation rate/s, $\mathrm{A}$ is frequency factor/s, $\Delta E$ is activation energy $(\mathrm{KJ} / \mathrm{mol}), \mathrm{R}$ is universal gas constant $(0.00831 \mathrm{~kJ} / \mathrm{mol})$, and $\mathrm{T}$ is absolute temperature $(\mathrm{K})$.

$$
\log \left(\frac{k 2}{k 1}\right)-\left(\frac{-E \alpha}{2 \cdot 309 R}\right)\left(\frac{1}{T 2} \frac{1}{T 1}\right)
$$

From the equation (3), k1 and $\mathrm{k} 2$ are rate constants at temperature $\mathrm{T} 1$ and $\mathrm{T} 2$ in degree Kelvin, $\mathrm{Ea}$ is the activation energy and $\mathrm{R}$ is gas constant. From the both equations, it describes that the relationship between storage temperature and degradation rate.

\subsection{Scanning electron micrograph (SEM) of sodium alginate bead immobilizing bacteria}

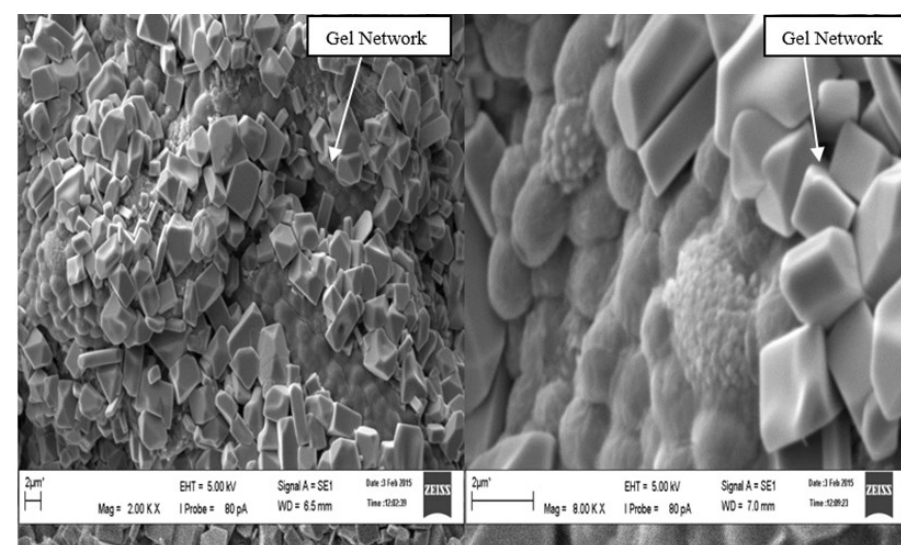

Figure 2. SEM image of sodium alginate bead immobilizing Lactobacillus plantarum sp. (BAA-793)

The external appearance and surface structure of the beads were observed using scanning electron microscope (SEM). Figure 2 shows the SEM image of calcium 
alginate bead of immobilized Lactobacillus plantarum sp. (BAA-793). Based on Figure 2 below, the microscopic examination shows the appearance of cloudiness, which was caused by gelatinous material and also fragmented hyphae without cellular content. Besides that, the result also shows that the Lactobacillus plantarum bacteria remained confined to the subsurface.

The previous research related to immobilization process using entrapment method of mycelia that was described by Kuek and Armitage, (1985) and Kuek, (1991) also mentioned that after observing the beads using electron microscopy, it was confirmed that the mycelia remained confined to the subsurface (Kuek, 1991). Besides that, there were appearances of corrugation on the surface of the bead, as shown in Figure 2, which was similar to the previous observation of Chen et al. (2012), which used scanning electron microscopy of Ca-alginate and alginate-chitosan beads containing Acetobacter cells (Chen et al., 2012).

\subsection{Reuse of immobilized cells in a batch process for sorbitol production}

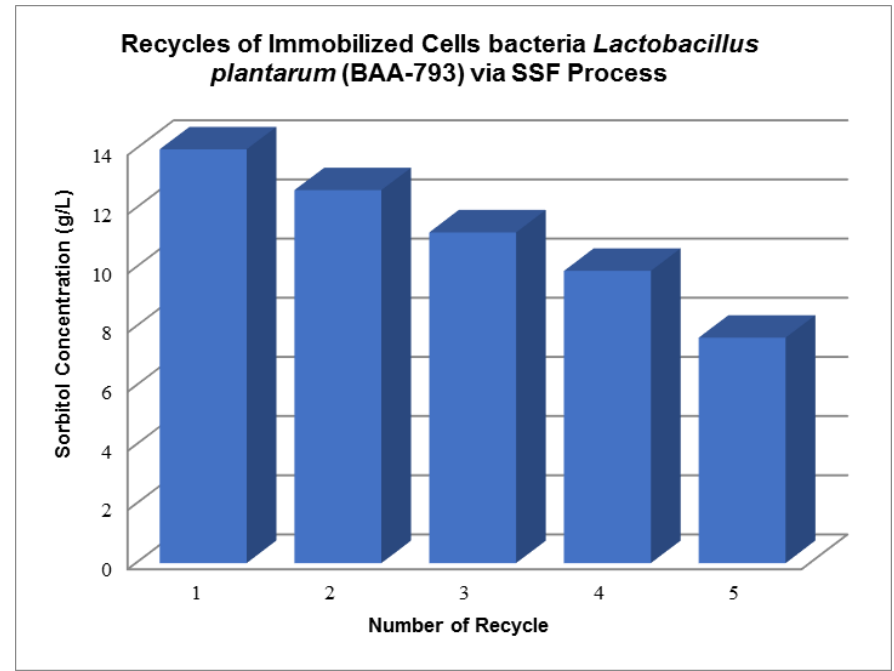

Figure 3. Recycles of immobilized cells bacteria Lactobacillus plantarum (BAA-793) via SSF process due to produce sorbitol

The cell immobilization process has many advantages and one is that the immobilized cells can be reused for repeated batch fermentation. In this research, the immobilized cells of Lactobacillus plantarum (BAA -793) via SSF process were reused after completing a cycle of the fermentation process. The immobilized cells of bacteria in gel beads that were used in the first fermentation batch of sorbitol were washed using sterilized distilled water in order to be reused for the next fermentation batch. The reuse of immobilized bacteria Lactobacillus plantarum (BAA-793) cells is very important from the point of view of reducing the cost of using the bacteria. Figure 3 shows the recycling of immobilized Lactobacillus plantarum (BAA-793) bacteria cells via SSF process in order to produce sorbitol.

From Figure 3, the data shows that sorbitol production was observed until the 5th cycle. The production of sorbitol was higher at cycle 1 , where the production was about $13.516 \mathrm{~g} / \mathrm{L}$. This is because the cell colonies on gel beads were at high concentrations when reacting with the fermentation medium and thus produced a high concentration of sorbitol. However, a gradual decrease was observed in the next cycle. The production of sorbitol for cycles 2, 3, 4 and 5 was $12.606 \mathrm{~g} / \mathrm{L}, \quad 11.178 \mathrm{~g} / \mathrm{L}, \quad 9.878 \mathrm{~g} / \mathrm{L}$ and $\quad 7.619 \mathrm{~g} / \mathrm{L}$, respectively. The production of sorbitol decreased after cycle 1 because the cells which were immobilized in sodium alginate in gel beads were leaking into the fermentation medium of the first batch/first cycle, hence reducing the number of cells attached to gel beads and therefore reducing sorbitol production for the next cycles. Besides that, the number of cells attached to gel beads possibly leaked when the gel beads were washed with sterile distilled water in order to start the next cycle, and thus the sorbitol production decreased.

Besides that, the profiles of the beads are not uniform and the beads also changed shape during fermentation from big shape to small shape. The changing shape of the beads used for immobilizing bacteria cells during fermentation has also been proven by other researchers (Yan et al., 2001). In addition, the researcher that used the immobilization process where entrapped protease in calcium alginate beads was reused reported that the decrease in activity occurred on further reuse, which was due to the leakage of enzymes from beads during washing time (Anwar et al., 2009; Geethanjali and Subash, 2013).

\section{Conclusion}

In summary, the immobilization of the Lactobacillus plantarum (BAA-793) in sodium alginate beads ensured the survival of a high number of the cells during storage at $4{ }^{\circ} \mathrm{C}$. It also led to a high sorbitol yield using solid state fermentation. In addition, the immobilized cells in the gel beads can be used repeatedly up to 5 times with good sorbitol yield.

\section{Acknowledgement}

The authors thank the support of Faculty of Chemical Engineering and Natural Resources, 
Universiti Malaysia Pahang (UMP) for providing the facilities.

\section{References}

Amenaghawon, N.A. and Oiwoh, O. (2015). Optimization of solid state fermentation of banana peels for citric acid production. Nigerian Journal of Technology, 34(4), 716-723.

Anderson, S.M., Brown, M.R. and McDonald, J.F. (1991). Tissue-specific expression of the drosophila adh gene: a comparison of in situ hybridization and immunocytochemistry. Genetica, 84, 95-100.

Anwar, A., Qader, S.A.U., Raiz, A., Iqbal, S. and Azhar, A. (2009). "Calcium alginate: a support material for immobilization of protease from newly isolated strain of Bacillus subtilis KIBGE-Has,". World Applied Sciences, 7(10), 1281-1286.

Bajaj, S., Singla, D. and Sakhuja, N. (2012). Stability testing of pharmaceutical products. Journal of Applied Pharmaceutical Science, 02(03),129-138.

Bangrak, P., Limtong, S. and Phisalaphong, M. (2011). Continuous ethanol production using immobilezed yeast cells entrapped in loofa-reinforce alginate carriers. Brazilian Journal of Microbiology, 42, 676684.

Bayat, Z., Hassanshahian, M. and Cappello, S. (2015). Immobilization of microbes for bioremediation of crude oil polluted environments: A mini review. The Open Microbiology Journal, 9, 48-54.

Behera, S., Mohanty, R.C. and Ray, R.C. (2011). Ethanol production from mahula (Madhucalatifolia L.) flowers using free and immobilized (in Luffacylindrical L.spongediscs) cells of Zymomonamobilis MTCC92. Annals of Microbiology, 61, 469-474.

Barros, M.D., Celligoi, M.A.P.C., Vignoli, J.A. and Vargas, L.H.M. (2006). Influence of ultrasound on sorbitol release by Zymomonas mobilis grown on high sucrose concentration. An International Journal Brazilian Archives of Biology and Technology, 49, 371-374.

Chen, X.H., Wang, X.T., Lou, W.Y., Wu, H., Zong, M.H., Smith, T.J. and Chen, X.D. (2012). Immobilization of Acetobactor sp.CCTCC M209061 for efficient asymmetric reduction of ketones and biocatalyst recycling. Microbial Cell Factories, 11, 1 -13 .

Cláudia, S., Martins, S., Martins, C. M., Maria, L., Guedes, C. and Santaella, S. T. 2013. Immobilization of microbial cells: A promising tool for treatment of toxic pollutants in industrial wastewater. African Journal of Biotechnology, 12(28), 4412-4418.

Fang, H., Zhao, C. and Song, X.Y. (2010). Optimization of enzymatic hydrolysis of steam-exploded corn stover by two approaches: response surface methodology or using cellulase from mixed culture of Trichoderma resei RUT-C30 and Aspergillus niger NL02. Bioresources Technology, 101, 41114119.

El-Borai, A.M., Youssef, A.S., El-Salam, A.E.A. and ElAssar, S.A. (2013). Optimization of keratinase production by Aspergillus terreus thom by statistical and immobilization methods. Life Science Journal, 10(3), 1833-1839.

Geethanjali, S. and Subash, A. (2013). Optimization and Immobilization of purified labeo rohita visceral protease by entrapment method. Enzyme Research, 2013, 1-7.

Gündüz, M. (2005). Lactic acid production by Lactobacillus casei NRRL B-441 immobilized in chitosan stabilized Ca-alginate beads. Graduate School of Engineering and Sciences. Turkey: Izmir Institute of Technology, MSc thesis.

Hsieh, C. and Yang, F.C. (2004). Reusing soy for the solid- state fermentation of ganoderma lucidum. Bioresources Technology, 91, 105-109.

Ibrahim, D., Salikin, N.H., Hong, L. S., Ahmad, R. and Weloosamy, H. (2013). Pomelo peels as alternative substrate for extracellular pectinaseproduction by Aspergillus niger HFM-8. Malaysian Journal of Microbiology, 9(4), 308-316.

Jack, T.R. and Zajic, J.E. (2006). The immobilization of whole cells. Advances in Biochemical Engineering and Biotechnology, 5, 125-145.

Kuek, C. (1991). Production of glucoamylase using Aspergillus phoenicus immobilized in calcium alginate beads. Applied Microbiology and Biotechnology, 35, 466-470.

Kuek, C. and Armitage, T.A. (1985). Scanning electron microscopic examination of calcium alginate beads immobilizing growing mycelia of Aspergillus phoenicus. Enzyme and Microbial Technology, 7, 121-125.

Kumar, A.M. and Murugalatha, N. (2012). Isolation of Lactobacillus plantarum from cow milk and screening for the presence of sugar alcohol producing. Journal of Microbiology and Antimicrobials, 4(1),16-22.

Lakshmi, B.K.M. and Hemalatha, K.P.J. (2015). 
Production of alkaline protease with immobilized cells of Bacillus Cereus strain S8 in various matrices. International Journal of Pharma and Bio Science, 6 (1), 135-144.

Ladero, V., Ramos, A., Wierama, A., Goffin, P., Schanok, A.,Kleerebezem, M., Hugonholtz, J., Smie, E.J. and Hols, P. (2007). High-level production of the low-calorie sugar sorbitol by Lactobacillus plantarum through metabollic engineering. Applied Environmental Microbiology, 73, 1864-1872.

Manpreet, S., Sawraj, S., Sachin, D., Pankaj, S. and Banerjee, U.C. (2005). Influence of process parameters on the production of metabolites in solidstate fermentation. Malaysian Journal of Microbiology, 1(2), 1-9.

Natarajan, K. and Rajendran, A. (2012). Evaluation and optimization of food-grade tannin acylhydrolase production by a probiotic Lactobacillus plantarum strain in submerged and solid state fermentation. Food and Bioproducts Processing, 90(4), 780-792.

Nezzal, A., Luc, A., Marleen, V., Geert, H. and Andreas, R. (2009). Polymorphism of sorbitol. Journal of Crystal Growth, 311, 3863-3870.

Pandey, A., Palni, L.M.S. and Bisht, D. (2001). Dominant fungi in the rhizosphere of established tea bushes and their interactions with the dominant bacteria under in situ conditions. Microbiological Research, 156, 377-382.

Pandey, A, Trivedi, P., Kumar, B., Chaurasia, B., Singh, S. and Palni, L.M.S. (2004). Development of microbial inoculants for enhancing plant performance in mountains. In Reddy, M.S. and Khanna, S., (Eds). Biotechnological Approaches for Sustainable Development, p. 13-20, New Delhi: Allied Publishers Pvt Limited.

Pandey, A., Soccol, C.R., Rodriguez-León, J.A. and Nigam, P. (2001). Production of organic acids by solid-state fermentation. In Solid-state fermentation in biotechnology -fundamentals and applications, $\mathrm{p}$. 113-126. New Delhi: Asiatech Publishers.

Pilkingtonn, P.H., Margaritis, A., Mensour, N.A. and Russell, I. (1998). Fundamentals of immobilised yeast cells for continuous beer fermentation: A review. Journal of Institute of Brewing, 104, 19-31.

Rusmawarni, R. (2011). Response surface optimization (RSM) of pretreatment of meranti sawdust for higher lignin degradation. Proceeding of 1st International Conference and Exhibition of Woman Engineer. Kuantan Pahang: Malaysia.

Sabu, A., Swati, C. and Pandey, A. (2008). Tannase production by Lactobacillus sp. ASR-SI under solid state fermentation. Process Biochemistry, 41, 575580 .

Saha, B.C. and Nakamura, L.K. (2003). Production of mannitol and lactic acid by fermentation with Lactobacillus intermedius NRRL B-3693†. Biotechnology and Bioengineering, 82(7), 864-871.

Saha, B. C. (2006). Production of mannitol from inulin by simultaneous enzymatic saccharification and fermentation with Lactobacillus intermedius NRRL B-3693. Enzyme and Microbial Technology, 39(5), 991-995.

Tallur, P.N., Mulla, S.I., Megadi, V.B., Talwar, M.P. and Ninnekar, H.Z. (2015). Biodegradation of cypermethrin by immobilized cells of Micrococcus sp . strain CPN 1. Brazilian Journal of Microbiology, 46(3), 667-672.

Yan, Ji., Bajpai, R. and Iannotti, E. (2001). Lactic acid fermentation from enzyme-thinned starch with immobilized Lactobacillus amylovorus. Chemical and Biochemical Engineering, 15(2), 59-63.

Ying, W., Ye, T., Bin, H., Hua-bing, Z., Jian-nan, B. and Bao-li, C. (2007). Biodegradation of phenol by free and immobilized Acinetobacter sp. strain PD12. Journal of Environmental Sciences, 9, 222-225.

Zhang, P.Y.H., Himmel, M.E. and Mielenz, J.R. (2006). Outlook for cellulase improvement: screening and selection strategies. Biotechnology Advances, 24, 452-481.

Zhao, X., Zhang, L. and Liu, D. (2008). Comparative study on chemical pretreatment method for improving enzymatic digestibility of crofton weed stem. Bioresources Technology, 99, 3729-3736. 